\title{
Treatment of Chronic Hepatitis C in HIV-Infected Patients with Interferon $\alpha$-2b Plus Ribavirin
}

\author{
MAYTE PÉREZ-OLMEDA, VINCENT SORIANO, VICTOR ASENSI, \\ DOLORES MORALES, MIRIAM ROMERO, ANNA OCHOA, FAUSTO SÁNCHEZ-MONTERO, \\ MIGUEL SANTIN, JOSEP GUARDIOLA, JESÚS BLANCH, MARINA NÚÑEZ, \\ INMACULADA JIMÉNEZ-NÁCHER, JAVIER GARCÍA-SAMANIEGO, \\ and THE HCV/HIV SPANISH STUDY GROUP*
}

\begin{abstract}
One hundred six HIV-infected patients with chronic hepatitis $\mathrm{C}$ virus (HCV) infection were randomized to receive ribavirin (RBV) $400 \mathrm{mg}$ bid plus interferon $\alpha-2 b$ (IFN- $\alpha$ ) at two different doses, $3 \mathrm{mU}$ tiw (control arm) or $5 \mathrm{mU}$ daily for the first 6 weeks, followed by $3 \mathrm{mU}$ tiw until completing 6 months of therapy (induction arm). All patients had CD4 counts above 350 cells/ $\mu$ l and $89 \%$ were taking antiretroviral therapy. Adverse effects leading to treatment discontinuation occurred in $12.3 \%$ of patients, a rate quite similar to that seen in HCV-monoinfected patients. Negative serum HCV-RNA values $(<60 \mathrm{IU} / \mathrm{ml})$ were recorded in $24.7 \%$ and $35.5 \%$ of patients at 3 and 6 months of therapy. However, in the intent-to-treat analysis, sustained response was reached by only $16 \%$ of patients $(22.4 \%$ in the on-treatment analysis). No differences between treatment arms were noticed. Patients with HCV genotypes 2 or 3 had a 7 -fold higher response rate than those with HCV genotypes 1 or 4 . Therefore, early, end-of-treatment, and sustained response rates are lower in HIV/HCV-coinfected patients treated with RBV/IFN- $\alpha$ combination therapy. Since HCV-related liver disease is currently one of the leading causes of morbidity and mortality among HIV-infected patients, new treatment options are urgently needed for coinfected individuals.
\end{abstract}

\section{INTRODUCTION}

$\mathbf{H}$ EPATITIS C VIRUs (HCV) infection is quite common among HIV-infected persons. For individuals who acquired HIV through parenteral routes (i.e., intravenous drug users or hemophiliacs), the rate of chronic HCV infection is above $75 \% .^{1,2}$ Given that the life expectancy of HIV-positive persons has improved dramatically since the introduction of highly active antiretroviral therapy, end-stage liver disease due to HCV is now a relevant and growing problem among $\mathrm{HCV} / \mathrm{HIV}$-coinfected patients. In fact, liver failure is currently the leading cause of death among HIV-infected persons in places where a large number of patients are former drug addicts. ${ }^{3-5}$

Combination therapy with interferon- $\alpha$ (IFN- $\alpha$ ) plus ribavirin (RBV) was the standard of care for treating HCV infection in HIV-negative individuals until recent times. ${ }^{6,7}$ More recently, a pegylated formulation of IFN- $\alpha$ has been used with higher success than the classic IFN- $\alpha,{ }^{8,9}$ and together with RBV is now the preferred treatment choice for chronic hepatitis C. ${ }^{10}$ A successful response to anti-HCV therapy requires the definitive elimination of the virus from the infected host, which may be presumed when serum HCV-RNA becomes undetectable 6 months after ending treatment. Overall, this sustained response (SR) is achieved using combination therapy in nearly $40 \%$ of patients treated with IFN- $\alpha$ plus RBV, ${ }^{11,12}$ and up to nearly $50 \%$ when pegylated IFN- $\alpha$ plus RBV is used. ${ }^{8,9}$ In any case, patients with HCV genotypes 2 or 3 show a higher response ( $\sim 3$-fold) than those with HCV genotypes 1 or $4 .^{8-12}$ Preliminary results suggest that using greater doses of IFN- $\alpha$ or a more frequent administration of the drug might increase the response rate, particularly in subjects carrying HCV genotype $1,{ }^{13,14}$ although side effects may then become a major issue.

Information on the efficacy and safety of combination therapy with IFN- $\alpha$ plus RBV in HCV/HIV-coinfected patients is

Instituto de Salud Carlos III, Madrid 28029, Spain

*See the Appendix for members of the HCV/HIV Spanish Study Group. 
limited to a few studies in which a small number of patients had been recruited, and often with unfavorable profiles, such as previous IFN- $\alpha$ experience, advanced stages of liver fibrosis, and/or low CD4 counts. ${ }^{15-18}$ Herein, we report the final results of a multicenter trial in which two different doses of IFN- $\alpha$ plus RBV were prescribed to a large group of not severely immunosuppressed HIV-positive individuals with chronic hepatitis $\mathrm{C}$, all naive for IFN- $\alpha$.

\section{PATIENTS AND METHODS}

\section{Patients}

The study begun in January 2000, and the recruitment period extended for 1 year. It was designed as an open, prospective, multicenter, randomized, comparative trial. It was approved by the Ethical Committee of each of the participating institutions. Inclusion criteria required age between 18 and 55 years, elevated transaminase levels (either ALT or AST) above 1.5 the upper normal limit during the preceding 6 months, reactivity to $\mathrm{HCV}$ antibodies, and the presence of serum HCVRNA. Although a liver biopsy was recommended before beginning therapy, it was not mandatory for recruitment in the trial. All patients were naive for IFN- $\alpha$.

Among the exclusion criteria were positivity for HBsAg, history of decompensated cirrhosis, platelet counts below 75,000 cells/ $\mu$ l, hemoglobin levels below $11 \mathrm{~g} / \mathrm{dl}$, previous history of severe psychiatric illness, autoimmune disease, current significant alcohol intake ( $>50 \mathrm{~g}$ daily), or any recent engagement in drug addiction practices. Moreover, only patients having HIV infection under control were recruited in the trial. Accordingly, only those with $\mathrm{CD}^{+}$counts above 350 cells/ $\mu$ l and plasma HIV-RNA below 5000 copies/ml, with or without antiretroviral therapy, were eligible. All patients gave informed consent before being included in the trial.

\section{Study medication}

Interferon- $\alpha$-2b (Intron A, Schering-Plough, Kenilworth, NJ) and ribavirin (Rebetol, Schering-Plough, Kenilworth, NJ) were the study drugs. Two doses of IFN- $\alpha$ were examined. In the control arm, standard doses of 3 megaunits three times per week were prescribed, whereas 5 megaunits of IFN- $\alpha$ were given daily for the first 6 weeks in subjects allocated into the induction arm. All patients were allowed to complete 6 months of therapy with standard doses of IFN- $\alpha$ ( 3 megaunits tiw) plus RBV. The dose of RBV was of $400 \mathrm{mg}$ bid in both treatment arms, irrespective of the weight of patients.

\section{Laboratory tests}

Baseline HCV-RNA was measured using a commercially available reverse transcriptase polymerase chain reaction (RT/PCR) assay (Cobas Amplicor HCV Monitor v2.0; Roche, Barcelona, Spain), which has a detection limit of $600 \mathrm{IU} / \mathrm{ml}$. HCV genotype was determined with a commercial strip hybridization test (LiPA HCV II; Bayer, Barcelona, Spain). The presence of serum HCV-RNA in subjects undergoing therapy and thereafter was examined using a qualitative assay (Cobas Amplicor HCV; Roche, Barcelona, Spain), which has a detection limit of $60 \mathrm{IU} / \mathrm{ml}$.
Plasma HIV-RNA was measured using the bDNA assay (Quantiplex v3.0, Bayer, Barcelona, Spain), which has a detection limit of 50 copies $/ \mathrm{ml}$. Absolute numbers of $\mathrm{CD}^{+}{ }^{+} \mathrm{T}$ cells in peripheral blood were determined by flow cytometry (Coulter, Madrid, Spain).

\section{Patient's monitoring}

All subjects recruited in the study were seen every 4 weeks after beginning treatment. Hemoglobin, platelets, leukocytes, transaminases, amylase, lactate, CD4 lymphocyte counts, and plasma HIV-RNA were recorded at each time point. After ending 6 months on therapy, visits were programmed every 3 months.

\section{Statistical analyses}

Results are expressed in absolute values and percentage. Continuous variables are expressed as mean values \pm standard deviation. Means were compared using the Mann-Whitney rank sum test. Categorical variables were compared using the Fisher's exact or the chi-square tests. Response rates were estimated on an intent-to-treat basis (missing $=$ failure) as well as considering only subjects on treatment. Univariate and multivariate logistic regression analyses were performed for examining the potential predictors of response to therapy. All $p$ values were two-tailed, and differences were considered significant when $p$ was below 0.05 . All data analyses were conducted using the SPSS for Windows, version 10.0 (SPSS Inc, Chicago, IL).

\section{RESULTS}

A total of 106 subjects (79\% male; mean age 37 years old) were recruited in 13 centers participating in the trial. A total of $89 \%$ of patients were under antiretroviral therapy. All treated subjects received triple or quadruple drug combinations, using generally two nucleoside analogs along with protease inhibitors $(37 \%)$ or nonnucleosides $(62 \%)$. Of note, $71 \%$ of patients were taking stavudine (d4T), $28 \%$ were on dideoxyinosine (ddl), and $25 \%$ on zidovudine (AZT).

HCV genotype distribution was 1 (55\%), 3 (34\%), and 4 (11\%). Mean plasma HCV-RNA at baseline was 2,011,565 $\mathrm{IU} / \mathrm{ml}$, and $54 \%$ of patients harbored $>800,000 \mathrm{IU} / \mathrm{ml}$. The main characteristics of the study population at baseline in the two treatment arms are recorded in Table 1. No significant differences were noted when comparing them.

Data on liver histology were available for only 24 subjects, given that biopsy was not mandatory in this trial. It should be noted that in all instances significant liver fibrosis (stages F2 to F4 using the Metavir score) were recognized, with different degrees of necroinflammation. Ten patients showed liver cirrhosis (F4).

Side effects of any grade were recorded in 93 of patients $(92 \%)$. In order of frequency, the most frequent were malaise $(69 \%)$, fever $(61 \%)$, mialgias $(51 \%)$, depression $(38 \%)$, nauseavomiting $(31 \%)$, anemia $(28 \%)$, weight loss $(26 \%)$, local inflammation at the site of injection $(18 \%)$, insomnia $(14 \%)$, thrombopenia (9\%), abdominal pain $(6 \%)$, and psychotic reaction $(3 \%)$.

A total of 30 subjects did not complete the study. Seventeen 
Table 1. Baseline Characteristics of the Study Population

\begin{tabular}{|c|c|c|c|}
\hline & Induction arm & Control arm & Total \\
\hline No. & $49(46 \%)$ & $57(54 \%)$ & 106 \\
\hline Gender (male) & $40(82 \%)$ & $44(77 \%)$ & $84(79 \%)$ \\
\hline Mean age (years) & $36.6 \pm 5.5$ & $37.2 \pm 5$ & $36.9 \pm 5.2$ \\
\hline $\begin{array}{l}\text { HIV transmission route } \\
\quad \text { (intravenous drug use) }\end{array}$ & $41(84 \%)$ & $46(81 \%)$ & $87(82 \%)$ \\
\hline Mean weight $(\mathrm{kg})$ & $69.6 \pm 9.1$ & $68.1 \pm 82$ & $69.1 \pm 10.2$ \\
\hline \multicolumn{4}{|l|}{ HCV genotypes } \\
\hline 1 or 4 & $32(65 \%)$ & $38(67 \%)$ & $70(66 \%)$ \\
\hline 2 or 3 & $17(35 \%)$ & $19(33 \%)$ & $36(34 \%)$ \\
\hline \multicolumn{4}{|l|}{ Serum HCV-RNA (IU/ml) } \\
\hline Mean & $1,772,482$ & $2,208,704$ & $2,011,565$ \\
\hline No. with $>800,000$ & $24(51 \%)$ & $32(56 \%)$ & $56(53 \%)$ \\
\hline Mean ALT levels (IU/ml) & $126.6 \pm 23.2$ & $118.2 \pm 26.4$ & $122.5 \pm 27.1$ \\
\hline Mean CD4 count (cells $/ \mu$ l) & $525 \pm 108$ & $496 \pm 124$ & $512 \pm 132$ \\
\hline $\begin{array}{l}\text { No. of patients on } \\
\text { antiretroviral therapy }\end{array}$ & $40(82 \%)$ & $54(95 \%)$ & $94(89 \%)$ \\
\hline
\end{tabular}

(16\%) were lost to follow-up; in some cases coincident with new engagement in drug addiction practices, changes of city to live, request to be in jail, etc. Treatment discontinuation due to adverse effects considered to be related to the study medication occurred in $13(12.3 \%)$ patients, seven from the induction arm and six from the control arm. The reasons are recorded in Table 2. Another three subjects showed grade 2-3 increases in serum amylases without clinical symptoms or just mild abdominal discomfort, which normalized after discontinuing anti-HCV therapy at the end of treatment. All three were taking ddI concomitantly. Another two subjects showed mild increases in lactate levels without clinical symptoms of lactic acidosis. Both were taking d4T. Hyperamylasemia and hyperlactatemia resolved in all these subjects after completing anti-HCV therapy and discontinuing IFN- $\alpha$ plus RBV. Of note, no patients withdrew therapy due to anemia, although two needed reductions in the RBV dose. Neither significant drops in the CD4 count nor increases in plasma HIV-RNA were seen, even in subjects in whom RBV was taking concomitantly with AZT or d4T. Of note, body weight declined a mean of $4.3 \mathrm{~kg}$ from baseline (mean of $69.2 \mathrm{~kg}$ ) among subjects who completed 6 months on therapy.

Serum HCV-RNA clearance at month 3 (early response) was seen in $20(24.7 \%)$ of 81 patients on treatment, whereas it was recorded in 27 (35.5\%) of 76 patients who completed 6 months of therapy (end-of-treatmentresponse,ETR). Relapses occurred in $10(37 \%)$ of them within the following 6 months. Thus, the overall SR rate in this trial was $22.4 \%(17 / 75)$. In the intent-totreat analyses these figures were $18.9 \%$ for early response, $25.5 \%$ for ETR, and $16 \%$ (17/106) for SR. No significant differences between treatment arms were noticed. Of note, $70 \%$ of responders carried HCV-3. Table 3 summarizes the response rates according to $\mathrm{HCV}$ genotypes in each treatment arm at different time points.

Table 4 shows the predictive value of reaching SR for several variables, including age, HCV genotype, serum HCVRNA, treatment arm, concomitant antiretroviral therapy, CD4 counts, and RBV dose. Only infection with HCV genotype 3 was significantly associated with a greater likelihood of reaching SR, both in univariate and multivariate analyses. Patients

Table 2. Side Effects Leading to Treatment Discontinuation

\begin{tabular}{|c|c|c|c|}
\hline $\begin{array}{l}\text { Patient } \\
\text { no. }\end{array}$ & Main adverse events & Treatment arm & $\begin{array}{c}\text { Time on treatment } \\
\text { (months) }\end{array}$ \\
\hline 1 & Malaise, fever & Induction & 1 \\
\hline 2 & Transaminase elevation & Induction & 1 \\
\hline 3 & Depression & Control & 3 \\
\hline 4 & Nausea, vomiting, abdominal pain & Control & 3 \\
\hline 5 & Fever, malaise & Control & 1 \\
\hline 6 & Psychotic reaction & Control & 1 \\
\hline 7 & Psychotic reaction & Control & 1 \\
\hline 8 & Malaise, mialgias, depression & Induction & 3 \\
\hline 9 & Thrombopenia & Control & 1 \\
\hline 10 & Depression & Induction & 1 \\
\hline 11 & Weight loss & Induction & 3 \\
\hline 12 & Malaise, jaundice & Induction & 3 \\
\hline 13 & Psychotic reaction & Control & 3 \\
\hline
\end{tabular}


Table 3. Negative Serum HCV-Rna According to HCV Genotypes at Different Time-Points Using Intent-to-Treat (ITT) and On-Treatment (OT) Analyses

\begin{tabular}{|c|c|c|c|c|c|c|c|c|c|}
\hline & \multicolumn{3}{|c|}{$\begin{array}{l}\text { Early response } \\
\text { (3 months })\end{array}$} & \multicolumn{3}{|c|}{$\begin{array}{l}\text { End-of-treatment response } \\
\text { (6 months })\end{array}$} & \multicolumn{3}{|c|}{$\begin{array}{l}\text { Sustained response } \\
\quad(12 \text { months })\end{array}$} \\
\hline & $\begin{array}{l}\text { Genotypes } \\
1 \text { and } 4\end{array}$ & $\begin{array}{l}\text { Genotypes } \\
2 \text { and } 3\end{array}$ & Total & $\begin{array}{l}\text { Genotypes } \\
1 \text { and } 4\end{array}$ & $\begin{array}{l}\text { Genotypes } \\
2 \text { and } 3\end{array}$ & Total & $\begin{array}{l}\text { Genotypes } \\
1 \text { and } 4\end{array}$ & $\begin{array}{l}\text { Genotypes } \\
2 \text { and } 3\end{array}$ & Total \\
\hline \multicolumn{10}{|c|}{ Induction arm } \\
\hline ITT & $1 / 32$ & $10 / 17$ & $\begin{array}{c}11 / 49 \\
(22.4 \%)\end{array}$ & $2 / 32$ & $11 / 17$ & $\begin{array}{c}13 / 49 \\
(26.5 \%)\end{array}$ & $1 / 32$ & $9 / 17$ & $\begin{array}{c}10 / 49 \\
(20.4 \%)\end{array}$ \\
\hline OT & $1 / 21$ & $10 / 14$ & $\begin{array}{c}11 / 35 \\
(31.4 \%)\end{array}$ & $2 / 20$ & $11 / 13$ & $\begin{array}{c}13 / 33 \\
(39.4 \%)\end{array}$ & $1 / 20$ & $9 / 13$ & $\begin{array}{c}10 / 33 \\
(30.3 \%)\end{array}$ \\
\hline \multicolumn{10}{|c|}{ Control arm } \\
\hline ITT & $3 / 38$ & $6 / 19$ & $\begin{array}{c}9 / 57 \\
(15.8 \%)\end{array}$ & $6 / 38$ & $8 / 19$ & $\begin{array}{c}14 / 57 \\
(24.6 \%)\end{array}$ & $3 / 38$ & $4 / 19$ & $\begin{array}{c}7 / 57 \\
(12.3 \%)\end{array}$ \\
\hline OT & $3 / 31$ & $6 / 15$ & $\begin{array}{c}9 / 46 \\
(19.6 \%)\end{array}$ & $6 / 29$ & $8 / 14$ & $\begin{array}{c}14 / 43 \\
(32.6 \%)\end{array}$ & $3 / 29$ & $4 / 14$ & $\begin{array}{c}7 / 43 \\
(16.3 \%)\end{array}$ \\
\hline
\end{tabular}

with HCV genotype 3 had a 7-fold higher chance of response than those with HCV genotypes 1 or 4 (OR, 9.7; 95\% confidence interval, 2.7 to $35.2 ; p=0.0001)$.

Although many subjects who reached SR had cleared HCVRNA 4 weeks after beginning therapy, seven $(41.2 \%)$ of them showed a delayed virological response, in three (17.6\%) of them even beyond 12 weeks of therapy, and this was independent of the HCV genotype.

\section{DISCUSSION}

This trial shows that combination therapy with IFN- $\alpha$ plus RBV is relatively safe in HIV-coinfected individuals with chronic hepatitis $\mathrm{C}$. Overall, treatment was discontinued due to adverse events in $12 \%$ of patients, a rate similar to that seen in HCV-monoinfected individuals. ${ }^{8-12}$ Moreover, unexpected side effects were not recorded, although three patients developed

Table 4. Variables Associated with the Achievement of Sustained Response

\begin{tabular}{|c|c|c|c|}
\hline & No. & $\begin{array}{c}\text { Rate of sustained } \\
\text { response }\end{array}$ & $\mathrm{p}$ \\
\hline \multicolumn{4}{|l|}{ Age (years) } \\
\hline$<40$ & 82 & $13(16 \%)$ & \multirow[t]{2}{*}{ n.s. ${ }^{a}$} \\
\hline$>40$ & 24 & $4(17 \%)$ & \\
\hline \multicolumn{4}{|c|}{ CD4 count (cells/ $\mu \mathrm{l})$} \\
\hline$>500$ & 79 & $13(17 \%)$ & \multirow[t]{2}{*}{ n.s. } \\
\hline$<500$ & 27 & $4(16 \%)$ & \\
\hline \multicolumn{4}{|c|}{ Baseline serum HCV-RNA (IU/ $\mu \mathrm{l})$} \\
\hline$<800,000$ & 49 & $11(22 \%)$ & \multirow[t]{2}{*}{ n.s. } \\
\hline$>800,000$ & 57 & $6(11 \%)$ & \\
\hline \multicolumn{4}{|l|}{ HCV genotype } \\
\hline 2 and 3 & 36 & $13(36 \%)$ & \multirow[t]{2}{*}{0.0001} \\
\hline 1 and 4 & 70 & $4(6 \%)$ & \\
\hline \multicolumn{4}{|l|}{ Ribavirin dose } \\
\hline$>10.6 \mathrm{mg} / \mathrm{kg}$ & 77 & $12(15.6 \%)$ & \multirow[t]{2}{*}{ n.s. } \\
\hline$<10.6 \mathrm{mg} / \mathrm{kg}$ & 29 & $5(17.2 \%)$ & \\
\hline \multicolumn{4}{|c|}{ Treatment modality } \\
\hline Induction arm & 49 & $10(20 \%)$ & \multirow[t]{2}{*}{ n.s. } \\
\hline Control arm & 57 & $7(12 \%)$ & \\
\hline \multicolumn{4}{|c|}{$\begin{array}{l}\text { Estimated duration of } \mathrm{HCV} \\
\text { infection (years) }\end{array}$} \\
\hline$<5$ & 21 & $2(10 \%)$ & \multirow[t]{2}{*}{ n.s. } \\
\hline$>5$ & 85 & $15(18 \%)$ & \\
\hline \multicolumn{4}{|c|}{ Antiretroviral therapy } \\
\hline No & 12 & $3(25 \%)$ & \multirow[t]{2}{*}{ n.s. } \\
\hline Yes & 94 & $14(15 \%)$ & \\
\hline
\end{tabular}

${ }^{\mathrm{a}} \mathrm{n} . \mathrm{s} .$, not significant. 
asymptomatic hyperamylasemia, which disappeared after discontinuing therapy. All of them were taking ddl concomitantly. Moreover, lactate levels increased slightly in two individuals, both of whom were taking d4T. Recently, reports of fatal development of lactic acidosis and/or pancreatitis have appeared in HIV/HCV-coinfected patients receiving concomitantly RBV with either $\mathrm{d} 4 \mathrm{~T}$ and/or ddI, particularly in the setting of cirrhosis. ${ }^{19-22}$ Although liver histology was not available in many of our patients, fibrosis in different extent was uniformly demonstrated, with liver cirrhosis in up to $40 \%$ of biopsied cases, in agreement with other reports that have proven advanced liver fibrosis in a high proportion of HIV/HCV-coinfected patients. $^{23-25}$ This circumstance should have favored the recognition of any of these complications in our series. Therefore, our data do not support the removal of $\mathrm{d} 4 \mathrm{~T}$ and/or ddI when treatment with RBV is planned, although close monitoring of symptoms, and amylase, lipase, and lactate levels may be warranted.

One interesting finding in our study was the recognition of a significant weight loss (4.3 kg on average within 6 months), which exceeded what is generally seen in HIV-negative individuals undergoing anti-HCV combination therapy. Long-term exposure to nucleoside analogs, and particularly $\mathrm{d} 4 \mathrm{~T}$, has been associated with lipoatrophy in HIV-infected patients, most likely throughout a mechanism of mitochondrial damage. ${ }^{26,27}$ We wonder whether a potentiation of this side effect of nucleoside analogs with RBV could account for our findings. In fact, more than two-thirds of the patients recruited in our trial were taking d4T. As occurs with the greater risk of pancreatitis when taking ddI and RBV, a significant weight loss might be another characteristic side effect resulting from the interaction of $\mathrm{RBV}$ with nucleoside analogs.

The SR rate of $22 \%$ recorded in this study ( $16 \%$ in the intent-to-treat analysis) is much lower than that seen in HIV-negative individuals with chronic hepatitis $\mathrm{C}$ treated with IFN- $\alpha$ and RBV. ${ }^{11,12}$ Several reasons may account for this fact. Some of them are related to the trial design, such as the decision to use low doses of RBV in subjects weighing more than $75 \mathrm{~kg}$ or to prescribe treatment for only 6 months in subjects with $\mathrm{HCV}$ genotypes 1 or 4 . The use of doses of RBV adjusted to body weight $(>10.6 \mathrm{mg} / \mathrm{kg}$ ) has recently been shown to result in greater response rates. ${ }^{8}$ We chose the $400 \mathrm{mg}$ bid fixed dose of RBV because of concern for potential deleterious interactions when concomitantly taking some antiretroviral drugs (i.e., anemia with AZT, or pancreatitis with ddI). ${ }^{17-22}$ It should be noted, however, that less than one-third of our study population received less than $10.6 \mathrm{mg} / \mathrm{kg}$ of $\mathrm{RBV}$, and that no significant differences were noticed when comparing the response rate achieved in those with or without RBV exposure above $10.6 \mathrm{mg} / \mathrm{kg}$.

A different consideration could apply to the short length of treatment in our trial for patients with HCV genotypes 1 or 4 . The prescription of anti-HCV therapy for only 6 months was mainly based on the concern for a greater risk of toxicity and of poor adherence when concomitantly taking IFN- $\alpha$ plus RBV along with triple antiretroviral drug combinations for long periods of time. Different studies have demonstrated that patients with HCV genotypes 1 or 4 experience a greater benefit when treatment is extended to 1 year. ${ }^{6,28}$ In our trial, only $5 \%$ of subjects with HCV genotypes 1 or 4 reached SR. Although this rate is clearly below expectations, it should be noted that the response in subjects with $\mathrm{HCV}$ genotype 3 occurred in only $36 \%$, which is half the response obtained in HIV-negative patients. $6,11,12$ Therefore, although the treatment schedule might have contributed to explaining the overall lower response rate seen in our trial, other factors most likely account for it.

Specific characteristics of HCV infection in the setting of $\mathrm{HIV}$, such as higher HCV load or greater HCV quasispecies diversity, both of which are considered to be predictors of poor response to anti-HCV therapy, ${ }^{28,29}$ could have contributed to the low response rate seen in our trial. Moreover, HIV-infected individuals may show a lower immune response against $\mathrm{HCV}$, and might support a weaker immune-mediated clearance activity to IFN- $\alpha$ and/or IFN- $\alpha$ plus RBV. Finally, the interaction between thymidine analogs (AZT and d4T) and RBV is not well known in vivo. Preliminary studies have reported no evidence of a reduced anti-HIV activity of AZT or d4T when RBV is coadministered..$^{30,31}$ However, no data exist on a possible reduced anti-HCV activity of RBV in the presence of AZT or d4T.

The recognition of early predictors of lack of an SR in patients receiving IFN- $\alpha$ plus RBV may allow us to stop earlier a medication that is poorly tolerated and would not benefit the patient. In HIV-negative individuals, the presence of serum HCV-RNA is detectable at different time points whereas being on treatment is a good predictor of lack of SR. ${ }^{6}$ Using IFN- $\alpha$ monotherapy, treatment discontinuation was recommended at 3 months in the presence of detectable serum HCV-RNA ${ }^{6}$; however, this decision-making time point was extended to 6 months using IFN- $\alpha$ plus RBV, since about $10 \%$ of subjects showed a delayed HCV-RNA clearance. ${ }^{12}$ No data are available so far on the best time to discontinue therapy in HIV/HCV-coinfected subjects receiving IFN- $\alpha$ plus RBV. This information is extremely important in this population, since anti-HCV treatment is frequently associated with side effects, ${ }^{32}$ is expensive, reduces dramatically the patient's quality of life, and, as stated before, there is growing concern on the risks of interactions between RBV and antiretroviraldrugs. ${ }^{17-22}$ In our trial, we specifically examined whether the recognition of negative serum HCV-RNA at different time points could be used for early therapy-off decision making. Negative serum HCV-RNA among subjects who later achieved SR was recognized in $62 \%$ of cases at month 1 and in $82.4 \%$ at month 3 . However, 3 of 17 subjects who reached SR cleared HCV-RNA after the third month of therapy. Of note, responders carrying HCV genotype 3 did not have an apparently faster HCV-RNA clearance than those with $\mathrm{HCV}$ genotypes 1 or 4 . In agreement with our findings, a recent report has pointed out that $\mathrm{HCV} / \mathrm{HIV}$-coinfected patients may show a delayed clearance of serum HCV-RNA under IFN- $\alpha{ }^{33}$ Therefore, our results suggest that monitoring the response to IFN- $\alpha$ plus RBV in HIV/HCV-coinfected patients with a sensitive HCV-RNA qualitative test does not permit us to discontinue treatment earlier presuming that SR will not occur. Further studies are needed to determine whether monitoring the response to anti-HCV treatment with an HCV-RNA quantitative assay, following what is standard practice in HIV infection, ${ }^{34}$ may allow us to recognize much earlier (just 1 or 3 months after beginning IFN- $\alpha$ plus RBV) a minimal drop (i.e., of $2 \log$ ), below which no treatment response should be expected, and therefore treatment discontinuation might be warranted. This has been recently proven to be useful in $\mathrm{HCV}$ monoinfected patients using pegylated IFN- $\alpha$ and RBV. ${ }^{9}$ As we 
enter an era in which HCV treatment is going to be aggressively pursued in HIV/HCV-coinfected persons, being able to recognize at early time points who will not benefit from an expensive and poor tolerated therapy must warrant more attention.

In summary, our results show that the combination of IFN- $\alpha$ plus RBV is relatively well tolerated in HIV/HCV-coinfected patients. The rate of treatment discontinuation found in this study $(12 \%)$ is similar to that seen in HIV-negative individuals, without the appearance of unexpected side effects. However, the SR rate was $22.4 \%$, which is lower than that seen in HIV-negative counterparts. Although the short duration of therapy (6 months) for patients carrying HCV-1 and/or the low dose of RBV ( $800 \mathrm{mg}$ bid) for patients with high weight could have contributed to explaining this limited benefit, other reasons are most likely involved, since early and end-of-treatment responses were equally much lower than those seen in HCVmonoinfected patients. This information should be useful for clinicians, who will need to balance on an individual basis who should be treated for chronic hepatitis $\mathrm{C}$. On one hand, the response rate to anti-HCV therapy seems to be lower in HIVcoinfected patients, and side effects may be frequent, including those resulting from the interaction with antiretroviral drugs. On the other hand, the benefit of curing HCV infection may impact positively on several aspects of HIV disease, including a much better tolerance of antiretroviral drugs, ${ }^{35}$ an amelioration or complete stop in the progression of liver disease to cirrhosis or even hepatocellular carcinoma, ${ }^{36}$ and a suppression of the deleterious effect that HCV seems to play on HIV disease progression..$^{37,38}$

\section{APPENDIX: MEMBERS OF THE HCV/HIV SPANISH STUDY GROUP}

Anna Ochoa and Javier Martínez-Lacasa, Mútua de Terrassa, Terrassa.

Mercé Roget, Hospital de Terrassa, Terrassa.

Juan González and José Ramón Arribas, Hospital La Paz, Madrid.

Dolores Morales and Miguel Colmenero, Hospital Virgen Macarena. Seville.

Francisco García de la Llana, Hospital Infanta Cristina, Badajoz.

Pilar Barrera, Hospital Reina Sofia, Córdoba.

Vicente Torrente and Carlos Alonso-Villaverde, Hospital de Sant Joan, Reus.

Miguel Santín, Hospital de Bellvitge, L'Hospitalet de Llobregat.

Josep Guardiola and Josep Cadafalch, Hospital de Sant Pau, Barcelona.

Fausto Sánchez-Montero, Complejo Hospitalario. Cáceres. Jesús Blanch, Javier García-Pont, and Lluis Moner, Hospital de Sant Camil, Barcelona.

Victor Asensi, Hospital Central de Asturias, Oviedo.

Mayte Pérez-Olmeda, Miriam Romero, Marina Núñez, Pablo Barreiro, Inmaculada.

Jiménez-Nácher, Javier García-Samaniego, and Vincent Soriano, Instituto de Salud Carlos III, Madrid.

\section{ACKNOWLEDGMENTS}

This work was supported in part by grants from AIES, RIS(project 173), RTIC G03/015, and CAM. We would like to thank Prof. Gonzalez-Lahoz for his continuous support.

\section{REFERENCES}

1. Bonacini $\mathrm{M}$ and Puoti $\mathrm{M}$ : Hepatitis $\mathrm{C}$ in patients with HIV infection. Arch Intern Med 2000;160:3365-3373.

2. Sherman K, Rouster S, Chung R, and Rajicic N: Hepatitis C virus prevalence among patients infected with HIV: A cross-sectional analysis of the US ACTG. Clin Infect Dis 2002;34:831-837.

3. Puoti M, Spinetti A, Ghezzi A, et al:: Mortality for liver disease in patients with HIV infection: A cohort study. J Acquir Immune Defic Syndr 2000;24:211-217.

4. Martín-Carbonero L, Soriano V, Valencia ME, García-Samaniego J, López M, and González-Lahoz J: Impact of chronic viral hepatitis on hospital admission and mortality in HIV-infected patients. AIDS Res Hum Retroviruses 2001;17:1467-1471.

5. Bica I, McGovern B, Dhar R, et al:: Increasing mortality due to end-stage liver disease in patients with HIV infection. $\underline{\text { Clin Infect }}$ Dis 2001;32:492-497.

6. EASL Panel: EASL Consensus Statement on hepatitis C. J Hepatol 1999;30:956-961.

7. Lauer $\mathrm{G}$ and Walker B: Hepatitis C virus infection. N Engl J Med 2001;345:41-52.

8. Manns M, McHutchison J, Gordon S, et al.: Peginterferon alfa-2b plus ribavirin compared with interferon alfa- $2 b$ plus ribavirin for initial treatment of chronic hepatitis C: A randomized trial. Lancet 2001;358:958-965.

9. Fried M, Shiffman M, Reddy R, et al.: Peginterferon alfa-2a plus ribavirin for chronic hepatitis $\mathrm{C}$ virus infection. $\mathrm{N}$ Engl J Med 2002;347:975-982.

10. NIH Consensus Development Conference Statement: Management of hepatitis C. Gastroenterology 2002;123:2082-2099.

11. McHutchison J, Gordon S, Schiff E, et al.: Interferon alfa-2b alone or in combination with ribavirin as initial treatment for chronic hepatitis C. N Engl J Med 1998;339:1485-1492.

12. Poynard T, Marcellin P, Lee S, et al.: Randomized trial of interferon alpha $2 \mathrm{~b}$ plus ribaviron for 48 weeks or for 24 weeks versus interferon alpha $2 \mathrm{~b}$ plus placebo for 48 weeks for treatment of chronic infection with hepatitis C virus. Lancet 1998;352:14261432.

13. Bruno R, Sacchi $\mathrm{P}$, Maffezzini E, et al.: Daily interferon regimen for chronic hepatitis C: A prospective randomized study. Clin Drug Invest 1999;18:11-16.

14. Ferenci P, Brunner H, Nachbaur K, et al.: Combination of interferon induction therapy and ribavirin in chronic hepatitis $\mathrm{C}$. $\mathrm{He}-$ patology 2001;34:1006-1011.

15. Landau A, Batisse D, Piketty C, et al.: Long-term efficacy of combination therapy with interferon $\alpha$-2b and ribavirin for severe chronic hepatitis C in HIV-infected patients. AIDS 2001;15:21492156.

16. Nasti G, Di Gennaro G, Tavio M, et al.: Chronic hepatitis C in HIV infection: Feasibility and sustained efficacy of therapy with interferon alfa-2b and ribavirin. AIDS 2001;15:1783-1788.

17. Sauleda S, Juárez A, Esteban JI, et al.: Interferon and ribavirin combination therapy for chronic hepatitis C in HIV-infected patients with congenital coagulation disorders. Hepatology 2001;34: 1035-1040.

18. Rockstroh J, Mudar M, Lichterfeld M, et al.: Pilot study of interferon alpha high-dose induction therapy in combination with rib- 
avirin for chronic hepatitis $\mathrm{C}$ in HIV-coinfected patients. AIDS 2002;16:2083-2085.

19. Lafeuillade A, Hittinger G, and Chapadaud S: Increased mitochondrial toxicity with ribavirin in HIV/HCV coinfection. Lancet 2001;357:280-281.

20. Kakuda $\mathrm{T}$ and Brinkman $\mathrm{K}$ : Mitochondrial toxic effects of ribavirin. Lancet 2001;357:1802-1803.

21. Salmon-Ceron D, Chauvelot-Moachon L, Abad S, Silbermann B, and Sogni P: Mitochondrial toxic effects of ribavirin. Lancet 2001; 357:1803-1804

22. Mauss S, Larrey D, Valenti W, et al:: Risk factors for hepatic decompensation in cirrhotic patients with HIV-HCV coinfection treated with PEG interferon or interferon and ribavirin or placebo. Sixth International Congress on Drug Therapy in HIV Infection, Glasgow, November 17-21, 2002 [abstract PL12.4].

23. García-Samaniego J, Soriano V, Castilla J, et al.: Influence of HCV genotypes and HIV infection on histological severity of chronic hepatitis C. Am J Gastroenterol 1997;92:1130-1134.

24. Benhamou Y, Bochet M, Di Martino V, et al.: Liver fibrosis progression in HIV and HCV coinfected patients. Hepatology 1999;30: 1054-1058.

25. Soriano V, Martín-Carbonero L, and García-Samaniego J: Treatment of chronic hepatitis $\mathrm{C}$ virus infection: We must target the virus or liver fibrosis? AIDS 2003;17:751-753.

26. Moyle G: Hyperlactatemia and lactic acidosis during antiretroviral therapy: Causes, management and possible etiologies. AIDS Rev 2001;3:150-156.

27. Martínez E, Mocroft A, García-Viejo MA, et al.: Risk of lipodystrophy in HIV-infected patients treated with protease inhibitors: A prospective cohort study. Lancet 2001;357:592-598.

28. Poynard T, McHutchison J, Goodman Z, Ling M, and Albrecht J: Is an "à la carte" combination interferon alfa $2 \mathrm{~b}$ plus ribavirin regimen possible for the first line treatment in patients with chronic hepatitis C? Hepatology 2000;31:211-218.

29. Martinot-Peignoux M, Marcellin P, Poureau M, et al.: Pre-treatment HCV-RNA levels and HCV genotype are the main and independent prognostic factors of sustained response to alpha interferon therapy in chronic hepatitis C. Hepatology 1995;22:10501056.

30. Morsica G, De Bona A, Uberti C, Sitia G, Finzazzi R, and Laz- zarin A: Ribavirin therapy for chronic hepatitis $\mathrm{C}$ does not modify HIV viral load in HIV-1 positive patients under antiretroviral treatment. AIDS 2000;14:1656-1658.

31. Landau A, Batisse D, Piketty C, Jian R, and Kazatchkine M. Lack of interference between ribavirin and nucleoside analogues in $\mathrm{HIV} / \mathrm{HCV}$ coinfected individuals undergoing concomitant antiretroviral therapy. AIDS 2000;14:1857-1858.

32. Torriani F, Ribeiro R, Gilbert T, et al:: Early HCV viral dynamics in HIV/HCV-infected patients on HCV treatment. Ninth Conference on Retroviruses and Opportunistic Infections, Seattle, February 2002 [abstract 121].

33. Gervais A, Boyer N, and Marcellin P: Tolerability of treatments for viral hepatitis. Drug Safety 2001;24:375-384.

34. DHHS: Updated guidelines for the use of antiretroviral agents in HIV-infected adults and adolescents, February 4, 2002. http://www.hivatis.org/guidelines/adult/Feb04/AdultGdl.pdf.

35. Núñez M, Lana R, Mendoza JL, Martín-Carbonero L, and Soriano $\mathrm{V}$ : Risk factors for severe hepatic injury after introduction of highly active antiretroviral therapy. J Acquir Immune Defic Syndr 2001; 27:426-431.

36. García-Samaniego J, Rodríguez M, Berenguer J, RodríguezRosado R, Asensi V, and Soriano V. Hepatocellular carcinoma in HIV-infected patients with chronic hepatitis C. Am J Gastroenterol 2001;96:179-183.

37. Greub G, Ledergerber B, Battegay M, et al.: Clinical progression, survival, and immune recovery during antiretroviral therapy in patients with HIV-1 and hepatitis C virus coinfections. Lancet 2000 356:1800-1805.

38. Soriano V, Martín JC, and González-Lahoz J: HIV-1 progression in hepatitis C-infected drug users. Lancet 2001;357:1361-1362.

Address reprint requests to: Vincent Soriano

Service of Infectious Diseases

Instituto de Salud Carlos III

Calle Sinesio Delgado 10

Madrid 28029, Spain

E-mail:vsoriano@dragonetes 